\title{
EFFECT OF MORINGAOLEIFERALAM LEAVES SUPPLEMENTATION ON RUMEN FERMENTATION, DIGESTIBILITY, FREE RADICALS AND PRODUCTIVE PERFORMANCE OF GROWING LAMBS
}

\author{
G.H. Zaza; K.I. Mohamed; Hanim A. Elsheik and Afaf H. Zedan \\ Utilization of By-Products Research Department, Animal Production Research Institute, Agricultural \\ Research Center, Dokki, Giza, Egypt.
}

SUMMARY

$\mathrm{T}$ The objective of this research was to study the antioxidant propertyofMoringaoleifra L leaves as feed supplement and its effect on nutrient intake, digestibility, nitrogen balance, and rumen fermentation and growth performance parameters of Rahmanisheep. Twenty one Rahmani lambs averaged $(17 \pm 0.12 \mathrm{~kg})$ body weight and 4 months old were divided into 3 groups, (7 animals each)in a completely randomized design experiment. Experimentalanimals were fed on concentrate feed mixture (CFM) and clover hay $(\mathrm{CH})$ with different levels of Moringaoleifera leaves 0, (R1-control); $10 \mathrm{gm} / \mathrm{kg}$ of the ration (R2) and $20 \mathrm{~g}$ of the ration / $\mathrm{Kg}(\mathrm{R} 3)$, respectively in a feeding trial lasted for 90 days.Obtained results indicated thatR3 and R2groups fed rations supplemented with 20 and 10 gmMoringa leaves per $\mathrm{kg}$ of ration recorded the highest $(\mathrm{P}<0.05)$ EE digestibility compared with the $\mathrm{R} 1$, (control). $\mathrm{R} 3$ recoded higher $(\mathrm{P}<0.05)$ digestibility values of $\mathrm{CP}$ and NFE compared with R1 while differences were insignificantcompared with R2 as well as between R2 and R1.Insignificant differences $(\mathrm{P}<0.05)$ were observed among the three treatments in the digestibility of $\mathrm{OM}$, $\mathrm{CF}$ and its fractions (NDF and $\mathrm{ADF})$. R2 also recorded significantly $(\mathrm{P}<0.05)$ higher TDN values comparedwith R1, while between R3 and R1, differences were not significant. Both R3and R2 were significantly $(\mathrm{P}<0.05)$ higher in their nitrogen balance compared to R1.No significant differences were observed in $\mathrm{pH}$ values of rumen among three treatments at 0,2 and 4 hours sampling time while at 6 hours R1 showed high $(\mathrm{P}<0.05) \mathrm{pH}$ value compared with $\mathrm{R} 2$ and $\mathrm{R} 3$. R3 and $\mathrm{R} 2$ recorded $(\mathrm{P}<0.05)$ higher values of $\mathrm{NH}_{3} \mathrm{~N}$ at all sampling times. The same trend was observed that $\mathrm{R} 3$ and $\mathrm{R} 2$ recorded $(\mathrm{P}<0.05)$ higher values of rumen TVFA, s compared with R1.No significant difference among R3 and R2 in the values of glutathione peroxidase in the serum of tested animalscompared with control, while, R3 and $\mathrm{R} 2$ recorded $(\mathrm{P}<0.05)$ higher values of serum Glutathione reductase compared with R1. Regarding to non- enzymatic anti-oxidants, R3 and $\mathrm{R} 2$ recoded $(\mathrm{P}<0.05)$ high concentration of Vit. $\mathrm{C}$, Vit. E and zinc compared to R1.R3 and R2 recorded $(\mathrm{P}<$ 0.05 ) higher values of final body weight, weight gain and average daily weight gain and FCR compared with R1.It could be concluded that Moringaoleifera leaves are suitable feedsupplement at 10 or $20 \mathrm{~g} / \mathrm{kg}$ of feed without any adverse effect on the performance of Rahmani lambs.

Keywords: Anti-oxidants Digestibility, growth performance, Rahmani sheep, Moringa.

\section{INTRODUCTION}

Performance ofruminants was reported to be low due to some factors such as feed shortage (quality or quantity) and health constraints (Tsedeke, 2007).Feed shortage is one of the obstacles' facing development of animal productionsector Therefore, many attempts have been made to the improve performance of animals using feed additives (Pluske, 2013).The World Health Organization (WHO) encourages using of medicinal herbs to reduce the use of drugs and chemicals as a Global trend to return to natural nutrients (Mohamed et al., 2003). Dietary antioxidants in medicinal herbs, such as vitamins and minerals play an important role in the performance of animals (El-Shahat and Abdel Monem, 2011) and improving digestion by enhancing the bile secretion and pancreatic enzyme activity (Platelet al.,2002) and hepatic metabolism (Ayotundeet al., 2011). Antioxidants are free radical scavengers; functioning to protect cells against oxidative damage which reduced risk of toxicity and minimum health hazards (Devegowda, 1996).Among herbal plants, MoringaOleiferaLamhas been recorded higher demandfor its medicinal value as a good source of multi natural antioxidants such as ascorbic acid, flavonoids, phenolics and carotenoids (Anwar $e t$

The $16^{\text {th }}$ Scientific Conference for Animal Nutrition, Luxor-Aswan, $28^{\text {th }}$ Nov. $-1^{\text {th }}$ Dec., 2017 
al., 2007; Makkar and Becker, 1996) and amino acids (Olugbemietal., 2010).MoringaOleiferaLamis native to North India and fortunately, itis well distributed in many countries of tropics and subtropics (Anwar $e t$ al., 2007) widely distributed in the Philippines, Cambodia and Central, North and South America (Morton, 1991), Africa and South Asia (Fahey, 2005). It is used for food, medication and industrial purposes.Moringaoleifera extract wasreported to have antibacterial properties and conclusion was made to investigate it as a phototherapeutic agent to combat infectious agents (Patel, 2011). Most parts of the plant havebeen used in folk medicine in Africa and South Asia (Fahey, 2005). Sofidiyaet al., (2006) and Ogbunugaforet al., (2011), reported that the medicinal effects ofMoringawas ascribed to their possession of anti-oxidants, which are known to suppressformation of reactive oxygen species (ROS) and free radicals on the other hand plants generally contain chemical compounds such as saponins, tannins, oxalates,phytates, trypsin inhibitors and cyanogenic glycosides known as secondary metabolites, which are biologically active (Soetan and Oyewole, 2009). Plants are also known to possess high amounts of essential nutrients, vitamins, minerals and fattyacids and fiber (Gafar and Itodo, 2011). The plant was also claimed to boost immune systems (Jayavardhananet al., 1994;Fuglier, 1999 andOlugbemiet al., 2010)).The leaves and green fresh pods are rich in carotene and ascorbic acid (vitamin C) with a good profileof amino acids (Makkar and Becker 1996 and Ogbunugaforet al., 2011).This study therefore aimed at evaluating the chemical and nutritional composition ofMoringaOleifera, and to highlight its potential as feed supplement andmedicinal benefits as natural antioxidants in diets of sheep on intake, digestibility, growth performance, rumen parameters and blood ant oxidativestatus.

\section{MATERIALS AND METHODS}

This study was carried out into two stages: First stage, the digestibility trial, was conducted at the animalexperimental house of Animal Production Research Institute for a period of 28days, while second stage was for the growth trial which carried out at Mallawy Experimental Station, El-Meniagovernorate and lasted for 90 days. The two places are belonging to the Animal Production Research Institute.

\section{Digestibility and rumen fermentation:}

\section{Animals and experimental design:}

Three healthy Osimi rams $(54 \pm 2.3 \mathrm{~kg})$ per treatment were housed individually inmetabolic cages at room temperature and used in three consecutive trials for nutrient feed intake and digestibility determination, while three Osimi rams $(50 \pm 3.6 \mathrm{~kg})$ per treatment fitted with a permanent rumen fistula, were used as rumen fluid donors.Rams were fed on a basal diet formulated with different levels of MoringaOleiferaleaves ( 0.10 and $20 \mathrm{~g} / \mathrm{Kg}$; respectively) to meet their maintenance requirements (NRC, 1985) composed of roughage: concentrate ratio 30:70, respectively with ad libaccess to water. The period of this study was 28 days whereas; rams received the basal diet for three weeks as preliminary period and one week for sample collection.

\section{Chemical analysis:}

Feed ingredients, Moringa leaves powders, concentrate feed mixture CFM, clover hay $\mathrm{CH}$ and feces were analyzed for proximate analysis according to AOAC (1990)whereas, nitrogen free extract was calculated by difference. Fiber fractions (NDF and ADF) were analyzed according to (Van Soest., 1994).Nitrogen in urine was determined by micro-kjedahl methods. Nitrogen free extract was calculated by the difference of the sum of all the proximate composition from $100 \%$. The chemical compositions of feed ingredients are presented in Table (1 and 2).

\section{Rumen liquor:}

Rumen liquor samples $(100 \mathrm{ml})$ were collected from each animal (tree rumen fistulaeted Ossimi rams per treatment) at 4 times, just before morning feeding, 0, 2, 4 and 6hours post-feeding.pHvalues were immediately recorded after collection using a hand $\mathrm{pH}$ meter (Orin-Res-EARH, model 30). Rumen liquor samples were filtered through 4 layers of cheesecloth followed by acidified with $0.1 \mathrm{~N}$ hydrochloric acid and concentrated orthophosphoric acid and stored by freezing for determination of $\mathrm{NH}_{3}-\mathrm{N}$ concentration using MgO distillation method (Al- Rabbat et al., 1971) and the concentration of TVFA, s were estimated 
in rumen liquor by the steam distillation method as described by Warner (1964) using Mrkham micro distillation apparatus.

\section{Feedlot performance:}

Twenty one Rahmani lambs averaged $17 \pm 0.12 \mathrm{~kg}$ body weight and 4 months old were divided into 3 groups of 7 animals each according to live weight for 90 days trial. Animals were weighed individually firstly and biweekly until the end of the experimental period. The growing lambs were fed (in groups) CFM and $\mathrm{CH}$ with different levels of Moringa oleifera leaves (0.10 and $20 \mathrm{~g} / \mathrm{Kg}$ of ration, respectively) twice a dayat $8 \mathrm{AM}$ and $4 \mathrm{PM}$ and the remaining amounts from the previous day were measured.Water was offered freely all the day round. The CFM was adjusted biweekly according to the body weight changes. Daily feed intake, daily body weight gain were recorded and feed efficiency ( $\mathrm{g}$ feed/g gain) were calculated accordingly. Lambs were weighted biweekly before morning feeding after 17 hours fasting period.Experimental rations were offered as $70 \%$ CFM and 30\% roughage) were offered at 3\% of live body weight (LBW).The concentrates feed mixture (CFM) composed of yellow corn grain (55\%), wheat bran $(20 \%)$, soybean meal $(10 \%)$, cottonseed meal $(12.50 \%)$, sodium chloride $(1 \%)$, limestone $(1.3 \%)$ and avitamins-minerals mixture $(0.2 \%)$.

\section{Blood collection and analyses:}

The blood samples were taken at the end of termination of the experiment from the jugular vein in dry clean glasses tubes. Each blood samples were divided into two portions; the first portions were poured in tubes without anticoagulant for determination of serum total antioxidant capacity (TAC) and nonenzymatic antioxidants (Vitamin C, Vitamin E, Zinc (Zn) Selenium (Se)by using commercial kits. The second portions were poured in tubes containing 20 IU heparin as anticoagulant and then centrifuged for 15 minutes at $4000 \mathrm{rpm}$ to obtain plasma were used for determination of glutathione peroxidase (GSH-Px) and glutathione reductase (GR-ase) according to Pagelia and Valentine (1967).

\section{Statistical analysis:}

Analysis of variance (one-way, ANOVA) was performed to compare between different groups .Statistical analysis was carried out using SAS (2003) and Duncan's multiple range Test (Duncan, 1955) was used to separate the means when the main effect was significant.). The following model was used:

$\mathrm{Yij}=\mu+\mathrm{Ti}+\mathrm{eij}$

Where: $\mathrm{Yij}=$ Individual observation,$\quad \mu=$ overall mean, $\mathrm{Ti}=$ effect of treatment, eij $=$ random error

\section{RESULTS AND DISCUSSION}

\section{Chemical composition:}

The proximate composition of Moringa leaves and experimental feed ingredients and the formulated rations are shown in Tables (1 and 2). Asshownin Table (1), the crude protein (CP) content of Moringa is 24.44 and it exceeds by far the minimum protein requirements for ruminants recommended by ARC (1985).Very close results to that recorded in this research were reported by Makkar and Becker (1996) and Manh et al. (2005) whom obtained CP values of 25.1 and $26.4 \%$ respectively while Odee (1998) reported a CP content of $29 \%$ for M. Oleifera. Variability in the nutrient content of browses has been attributed to within species differences, plant parts, season, harvesting regime, location, soil type and age (Norton 1994). Other studieshave reported variable protein contents ranging between 16, 22.42, 23.27, 27.4 and 40\% (Moyo et al , 2011; Gidamis et al., 2003;Sarwatt et al., 2004; Nouala et al., 2006; Reyes-Sanchez et al., 2006; Oduro et al., 2008 and Sanchez-Machado et al.,2009).This level of crude protein content is of particular nutritional significance as it may meet animal's protein and energy requirements and boost the immune system against diseases (Kyriazakis and Houdijk, 2006; Brisibe et al., 2009 and Moyo et al, 2011). Moringa was reported to have high quality protein whichis easily digested and that is influenced by the quality of its amino acids (Foidl et al., 2001). Ogbeand John, (2011) reported that Moringa leave proximate analysis revealed the presence of high crude protein $(17.01 \% \pm 0.1)$ and carbohydrate $(63.11 \%$ $\pm 0.09)$. The leaves also contained appreciableamounts of crude fiber $(7.09 \% \pm 0.11)$, ash $(7.93 \% \pm 0.12)$, crude fat $(2.11 \% \pm 0.11)$ and fattyacid $(1.69 \% \pm 0.09)$. The total ash content showed it contained minerals, 
$\mathrm{Ca}(1.91 \% \pm 0.08), \mathrm{K}(0.97 \% \pm 0.01), \mathrm{Na}(192.95 \pm 4.4), \mathrm{Fe}(107.48 \pm 8.2), \mathrm{Mn}(81.65 \pm 2.31), \mathrm{Zn}(60.06 \pm 0.3)$ and $\mathrm{P}(30.15 \pm 0.5)$ parts per million $(\mathrm{ppm})$. Magnesium $(0.38 \% \pm 0.01)$ and copper $(6.10 \pm 0.19)$ werethe least.As shown in Table (1) leaves of Moringa have high amounts of ascorbic acid, tocopherol vitamins, zinc and selenium minerals similar as reported by (Gafar and Itodo, 2011; Makkar and Becker, 1996).

\section{Digestibility coefficients and nutritive values:}

Data of digestibility trial in Table (3) showed thatR3 and R2 groups fed rations supplemented with 20 and $10 \mathrm{gm}$ Moringa leaves per $\mathrm{kg}$ of ration recorded the highest $(\mathrm{P}<0.05) \mathrm{EE}$ digestibility compared with the $\mathrm{R} 1$, (the control group). R3 recoded higher $(\mathrm{P}<0.05)$ digestibility values of $\mathrm{CP}$ and NFE compared with R1 while insignificant $(\mathrm{P}<0.05)$ between $\mathrm{R} 3$ and $\mathrm{R} 2$ and also between $\mathrm{R} 2$ and $\mathrm{R} 1$.This is probably because Moringa fodder consists of more degradable components especially crude protein (Fadiyimu et al., 2010). No significant difference was recorded among R3 R2 and R1 in thedigestibility values of OM, CF and its fractions (NDF and ADF). Regarding to Nutritive values of tested rations, R3 recorded significantly $(\mathrm{P}<0.05)$ higher TDN values compared to control while between R3 andR2 and between $\mathrm{R} 2$ and $\mathrm{R} 1$ differences were not significant. Both R3 and R2 were significantly $(\mathrm{P}<0.05)$ higher in their nitrogen balance compared with control. As shown in Table (3) DCPvalues of R3, R2 and R1were statistically insignificant. As shown in Table (3), level of Moringa supplementation was significant $(\mathrm{P}<0.05)$ for NFE digestibility suggesting that increasing level of Moringa supplementation will probably enhance the utilization of the soluble carbohydrate components of the dietary organic matter.

Table (3) depicts the nitrogen $(\mathrm{N})$ balance when Moringaleaves were fed to experimental sheep. N intake increased from control treatment to R3 3, hence it has significant $(\mathrm{P}<0.05)$ direct relationship with dietary level of Moringa. This is probably due to increased CP intake with increasing level of Moringa inclusion in the experimental diets as reported above. According to Brooker et al., (1995), when feed is high in soluble plant protein, $\mathrm{N}$ metabolism occur mainly in the rumen rather than in the lower digestive tracts leading to the production of large quantities of ammonia $\mathrm{N}$ in excess of the requirements of rumen microorganisms. The ammonia $\mathrm{N}$ not utilized by the bacteria is converted to urea by the animal and excreted in urine. This means that more rumen ammonia would be produced with the Moringasupplemented diets which would have increased as $\mathrm{N}$ intake increases from treatments 2 to 3 . This perhaps explains why values of total $\mathrm{N}$ output were recorded as the level of Moringasupplementation increased in this study. Fadiyimu et al., (2010) reported that M. oleifera had significantly higher crude protein intake, higher dry matter and nutrient digestibility's, higher nitrogen retention and better hematological profile in the supplemented than non-supplemented animals.

\section{Rumen liquor parameters:}

As given in Table (4), no significant differences $(\mathrm{P}<0.05)$ were observed in $\mathrm{pH}$ values of rumen among three treatments at 0,2 and 4 hours sampling time while at 6 hours control group (R1) showed higher $(\mathrm{P}<0.05)$ of $\mathrm{pH}$ value compared with $\mathrm{R} 2$ and $\mathrm{R} 3$ supplemented withMoringa leaves. The means of $\mathrm{pH}$ values of sheep in the three tested groups were within the normal range as mentioned by Hungate (1996) being 5.5 to 6.86 as shown in Table (4). Variations in $\mathrm{pH}$ values obtained in the present study could be explained that rumen $\mathrm{pH}$ values were varied according to the nature of diet, after feeding time and quantities of organic acids in the ingesta mentioned before by Phillipson (1970). Recorded values of $\mathrm{NH}_{3} \mathrm{~N}$ concentration as given in Table (4) indicated that the minimum $\mathrm{NH}_{3} \mathrm{~N}$ value was recorded at zero time and gradually increased to the maximum at 4 hours post feeding and tended to decrease again at 6hours post feeding. Groups of R3 and R2 supplemented with Moringa leaves recorded significantly $(\mathrm{P}<0.05)$ higher values of $\mathrm{NH}_{3} \mathrm{~N}$ in all times. The significant increase in $\mathrm{NH}_{3} \mathrm{~N}$ values in MoringaR3 and $\mathrm{R} 2$ than control could be attributed to the high content of soluble protein in Moringa leaves (Brookerel al., 1995).Ammonia-N concentration was found in this current study to be within the normal range described by Church (1976), being 10 to $45 \mathrm{mg} / 100 \mathrm{ml}$ depending on composition of the ration, time of sampling and method of analysis used. Also, Mehrez (1992) indicated that the optimal $\mathrm{NH}_{3}-\mathrm{N}$ concentration for maximum rate of fermentation in the rumen was affected by the dietary type and level of fermented energy in the rumen. The same trend was observed that R3 and R2 supplemented with Moringa recorded $(\mathrm{P}<0.05)$ higher values of rumen TVFA,s compared with control. Recorded values of TVFA,s concentration as given in Table (4) indicated that the minimum value was recorded at zero time and gradually increased to the maximum at 4 hours post feeding and tended to decrease again at 6hours post feeding. The highest value of TVFA's concentration was at 4 hours post feeding, which was reflected on $\mathrm{pH}$ values at the same time. 


\section{Antioxidant activity:}

Determination of enzymatic and non -enzymatic antioxidant in the serum of tested animal of the three treatments is shown in Table (5). Analyses of variance showed no significant difference among R3, R2 and $\mathrm{R} 1$ in the values of glutathione peroxidase in the serum of tested animals, while, R3 and R2 recorded $(\mathrm{P}<0.05)$ higher values of serum Glutathione reductase compared with control. Regarding to nonenzymatic anti-oxidants as shown in Table (5), R3 and $\mathrm{R} 2$ recoded $(\mathrm{P}<0.05)$ high concentration values of Vit. C, Vit. E, zinc and selenium compared with control. The same trend of significance was observed with values of the overall total antioxidant capacity. Yang et al. (2006) reported that with the survey of 120 edible plant species, Moringa oleifera were found among the most promisingspecies according to their high antioxidant activity, high contents of micronutrients and phyto-chemicals, processing properties, ease of growing and palatability. Yang et al. (2006) also reported that concentrations of four natural antioxidants (total phenolics and anti-oxidant vitamins A, C and E) were measured in four species of Moringaand found the content ranges on a dryweight basis were $74-210 \mu \mathrm{mol} / \mathrm{g}$ for phenolics, $70-100 \mu \mathrm{mol} / \mathrm{g}$ for ascorbate (Vit C), $1.1-2.8 \mu \mathrm{mol} / \mathrm{g}$ for $\beta$-carotene and $0.7-1.1 \mu \mathrm{mol} / \mathrm{g}$ for $\alpha$-tocopherol (Vit E). Antioxidant content of Moringas are high even compared to vegetables and fruitsknown for high antioxidant contents such as strawberries high in phenolics (330 mg gallic acid (GA)/100g fw, or $\sim 190 \mu \mathrm{mol} \mathrm{GA} / \mathrm{g} \mathrm{dw}$ ); hot pepper high in ascorbate $(200 \mathrm{mg} / 100 \mathrm{~g} \mathrm{fw}$, or $\sim 110 \mu \mathrm{mol} / \mathrm{g} \mathrm{dw})$, carrot high in $\beta$-carotene $(10 \mathrm{mg} / 100 \mathrm{~g} \mathrm{fw}$, or $\sim 1.8 \mu \mathrm{mol} / \mathrm{g} \mathrm{dw})$ and soybean which is high in $\alpha$-tocopherol $(0.85 \mathrm{mg} / 100 \mathrm{~g} \mathrm{fw}$, or $\sim 1.8 \mu \mathrm{mol} / \mathrm{g} \mathrm{dw})$. Moring isan excellent source of a wide spectrum of dietaryantioxidants. Moyo et al. (2011) reported that dried Moringa leaves had high levels of zinc (31.03 mg/kg) while, Barminas et al. (1998) reported $25.5 \mathrm{mg} / \mathrm{kg}$ indriedMoringa leaves. Zinc is essential for the synthesisof DNA, RNA, insulin and function and/or structure of several enzymes (Brisibe et al., 2009). Zinc is alsorequired for cellreproduction and growth especiallysperm cells. In addition, $\mathrm{Zn}$ is known for its anti-viral, anti-bacterial, anti-fungal and anti-cancer properties (Brisibe et al., 2009). Beta-carotene is the most potent precursor to vitamin A. Moringa is reported to be rich in vitamin $C$ whichincreases iron absorption in the animal's body (Anwar et al., 2007). Beta-carotene rich Moringaleaves can thus be animportant source of vitamin A, can be used for releasingthe bound iron status and thus, help in reducing anemia as well as prevalence of Vitamin A deficiency. Vitamin E with selenium contains antioxidant that workco-dependently in the body to help destroy free radicals(Rock et al., 2001). The interaction of selenium andimmune function focuses around the seleno-protein, glutathione peroxidase. Gluthione peroxidase inactivatesoxygen radicals such as hydrogen peroxide and preventsthem causing cellular damage.

\section{Growth performance:}

As illustrated in Table (6), groups R3 and R2 fed rations supplemented with Moringa leaves at levels 20 and $10 \mathrm{gm} / \mathrm{kg}$ of the tested rations recorded $(\mathrm{P}<0.05)$ higher values of final body weight, weight gain and average daily weight gain compared with control. Regarding to feed intake, no significant difference were found among three treatments in DM, TDN intake while groups in R3 and R2 had ( $>>0.05)$ higher CP intake compared with control. Moringa is reported to have high quality protein whichis easily digested and that is influenced by the quality of its amino acids (Foidl et al., 2001). Groups fed R3 and R2 achieved (P< 0.05 ) higher FCR compared with control. This positive achievement in FCR by R3and R2 could be attributed to the significant effect of incorporation of dried Moringa leaves in rations fed to animals of those groups on their rumen activities, nutrients digestibility and growth performance. Mahmoud (2013) reported that rations contained Moringa oleifera stems achieved higher feed efficiency than control rations with highly significant different and concluded that Moringa oleifera stems are suitable for feeding sheep and can be used to replace a part of clover hay or concentrate feed mixture without any adverse effect on the performance of Rahmani lambs. Worku (2016) reported that Moringa leaves totally replacing cottonseed cake in growing lambs fed on low-quality hay increased hay intake, diet DM digestibility and daily weight gain. Sultana et al. (2015) found that Bengal goat fed diet (75\% Moringa foliage and 25\% $\mathrm{CFM})$ recoded $(\mathrm{P}<0.05)$ the highest daily live weight gain compared with control. 


\section{CONCLUSION}

This study revealed that Moringaoleifera had high crude protein and lower crude fiber contents and its inclusion in the diets of sheep as supplement resulted in significantly higher crude protein intake, higher dry matter and nutrient digestibility's, higher nitrogen retention and better health and growth performance in the supplemented than non-supplemented animals at $10 \mathrm{or} 20 \mathrm{~g} / \mathrm{kg}$ of rations.

\section{REFERENCES}

AOAC. (1990). Official methods of analysis, Association of Official Analytical Chemists, Washington, D.C., USA. 15th Edition, pp. 807-928.

Akinyemi A. F., Julius A. A. and Adebowale N. F., (2010). Digestibility, Nitrogen balance and haematological profile of West African dwarf sheep fed dietary levels of Moringaoleifera as supplement to Panicum maximum. Journal of American Science, 2010;6(10).

Al-Rabbat, M.F.; R.L. Baldwin and W.C. Weir (1971).In vitro nitrogen-tracer technique for some kinetic measures of rumen ammonia.J.Dairy Sci., 54: 150.

Anwar, F., S. Latif, M. Ashrat and A.H. Gilani,( 2007). Moringaoleifera: A food plant with multiple medicinal uses. Phytother. Res., 21: 17-25.

ARC, (1985).Agricultural Research Council. The nutrient requirements of farm animals No 2: Ruminants. Washington D.C.

Ayotunde, E.O. - Fagbenro, O.A. and Adebanyo, O.T. 2011. Toxicity of aqueous extract of Moringaoleifera seed powder to Nile tilapia (Oreochromisniloticus) fingerlings. In International Research Journal of Agricultural Science, vol. 1, no. 4, p. 142-150.

Barminas JT, Charles M, Emmanuel D (1998). Mineral composition of non-conventional vegetables.Plant Food Hum.Nutri. 53: 29-36.

Brisibe EA, Umoren UE, Brisibe F, Magalhaes PM, Ferreira JFS, Luthria D, Wu X, Prior RL (2009).Nutritional characterization and antioxidant capacity of different tissues of Artemisia annua L. Food Chem. 115:1240-1246ed.), AOAC, Gaithersburg, MD.

Brooker JD, Lum DK, Miller S, Skene I and O'Donovan L (1995) Rumen microorganisms as providers of high quality protein. Livestock Research for Rural Development 6(3):

Church.D.C. (1976).Digestive Physiology and Nutrition Ruminants, Vol. 1.Digestive Physiology 145. 2nd Ed. 8 Books, Corvallis, Oregan.

Devegowda G., (1996),Herbal medicines, an untapped treasure in poultry production In: Proc. 20th World Poult. Congr. New Delhi, India, 1996.

Duncan, D.B. (1955). Multiple Range and Multiple F Test. Biometrics, 11:10.

El-Shahat, K. H.; Abdel Monem, U. M., (2011): Effects of dietary supplementation with vitamin E and/or selenium on metabolic and reproductive performance of Egyptian Baladi Ewes under subtropical conditions. World Applied Science Journal 12, 1492-1499.

Fadiyimu, A.A, Julius A.A. and Adebowale N. F., (2010). Digestibility, Nitrogen balance and haematological profile of West African dwarf sheep fed dietary levels of Moringaoleifera as supplement to Panicum maximum. nal of American Science 2010;6(10)

Fahey, J.W. (2005). Moringaoleifera: A review of the medical evidence for its nutritional, therapeutic and prophylactic properties. In Trees for Life Journal, vol. 1, pp. 5. 
Foidl N, Makkar HPS, Becker K (2001).The Potential of Moringaoleifera for Agricultural and industrial uses. What development potential for Moringa products? October 20 th- November 2nd 2001. Dar EsSalaam.Free-radical scavenging activity of some Nigerian medicinal plant extracts. In Pakistan

Fuglie LJ (2001). Combating malnutrition with Moringa. In: Lowell Fugile, J.(Ed), The Miracle Tree: The Multiple Attributes of Moringa CTA Publication, Wageningen, The Netherlands, pp. 117-136.

Fuglier, L.J. (1999). The Miracle Tree: Moringaoleifera, Natural Nutrition for the Tropics. Church World Service, Dakkar, Senegal, pp. 68.

Gafar, M.K. and Itodo, A.U. (2011).Proximate and mineral composition of hairy indigoleaves. In Electronic Journal of Environmental, Agricultural and Food Chemistry(EJEAFChe), vol. 10, no. 3, p. 2007-2018.

Gidamis AB, Panga JT, Sarwatt SV, Chove BE, Shayo NB (2003).Nutrients and anti-nutrient contents in raw and cooked leaves and mature pods of Moringaoleifera, Lam. Ecol. Food Nutr., 42: 399-411.

Hungate, R.E. (1996). The rumen and microbes.Academic Press. New York

Jayavardhanan, K.K, - Suresh, K, - Panikkar, K.R. and Vasudevan, D.M. (1994). Modular potency of drumstick lectin on host defense system. In Journal ofExperimental Clinical Cancer Research, vol. 13, p. 205-209.

Kyriazakis I and Houdijk JG (2006).Nutritional control of parasites. Small Ruminant Res., 62: 79-82.

Mahmoud, A.E.M. (2013). Effect of feeding on Moringaoleifera stems on productive performance of growing lambs. Egyptian J. Nutrition and Feeds (2013), 16(2) Special Issue: 281-292

Makkar, H.P.S. and Becker, K. (1996). Nutritional value and an nutritional components of whole and extracted Moringaoleiferaleaves. In Animal Feed Science and Technology, vol. 63, p. 211-228.

Manh LH, Dung NNX and Ngoi TP (2005) Introduction and evaluation of Moringaoleifera for biomass production and as feed for goats in the Mekong Delta. Livestock Research for Rural Development 17 (9). Retrieved from http://www.lrrd.org/lrrd17/9/manh17104.htm

Mehrez, A.Z. (1992). Influence of roughage: concentrate ratio on N-requirements of rumen microbes for maximal rate of fermentation. Proceedings of international conference on manipulation of rumen microorganisms to improve efficiency of fermentation and ruminant production, Alexandria, Egypt, 2023 September, $234 \mathrm{p}$.

Mohamed AH, El-Saidy BE, El-Seidy IA (2003). Influence of some medicinal plants supplementation: 1On digestibility, nutritive value, rumen fermentation and some blood biochemical parameters in sheep, Egyptian Journal of Nutrition and Feeds, 6(2), 2003, 139-150.

Morton, J.F. (1991), “The horseradish tree, Moringapterygosperma(Moringaceae) - a boon to arid lands ?", Economic Botany, Vol. 45 No. 3, pp. 318-333.no. 9, p. 223-232.

Moyo B, Patrick J. M, Arnold H. and Voster M., (2011). Nutritional characterization of Moringa (Moringaoleifera Lam.) leaves. African Journal of Biotechnology Vol. 10(60), pp. 12925-12933, 5 October, 2011

Norton BW (1994) Tree legume as dietary supplements for ruminants. In: R. C. Gutteridge and P. M. Shelton (eds.) Forage tree legumes in tropical agriculture. CAB International, Wallingford pp $202-$ 215.

Nouala FS, Akinbamijo OO, Adewum A, Hoffman E, Muetzel S, Becker K (2006). The influence of Moringaoleifera leaves as substitute to conventional concentrate on the in vitro gas production and digestibility of groundnut hay. Livest Res. Rural Dev., Vol. 18.

NRC, (1985). National Research Council Nutrient Requirements of Sheep Sixth Revised Edition, Subcommittee on Sheep Nutrition, Committee on Animal Nutrition, Board on Agriculture, Nation Research Council, National Academy Press, Washington, D.C., USA.. 
Odee D (1998) Forest biotechnology research in dry lands of Kenya: the development of Moringaspecies.Dryland Biodiversity, 2: 7-8.

Oduro I, Ellis WO, Owusu D (2008). Nutritional potential of two leafy vegetables: Moringaoleifera and Ipomoea batatas leaves. Sci. Res.Essays. 3(2): 057-060.

Ogbe, A.O. and John P, (2011).proximate study, mineral and anti-nutrient composition of moringaoleifera leaves harvested from lafia, nigeria: potential benefits in poultry nutrition and health AffikuJournal of Microbiology,Biotechnology and Food Sciences. Ogbe et al. 2011/12 : 1 (3) 296-308

Ogbunugafor, h.a, - Eneh, f.u, - Ezumba, a.n, - Igwo-ezikpe, m.n, - Okpuzor, j, - Igwilo, i.o, - Adenekan, s.o. and Onyekwelu, o.a. (2011).Physico-chemical and anti-oxidant properties of Moringaoleifera seed oil. In Pakistan Journal of Nutrition, vol. 10, no. 5, p. 409-414

Olugbemi, T.S, - Mutayoba, S.K. and Lekule, F.P.( 2010). Effect of Moringa (Moringaoleifera) Inclusion in Cassava based diets to broiler chickens. In InternationalJournal of Poultry Science, vol. 9, no. 4, p. 363-367.p. 241-247.

Paglia, D. E and W. N. Valentaine (1967). Studies on quantitative and qualitative characterization of erythrocyte glutathione peroxidase. J.Lab. Cli. Med, 70: 158-169..

Patel, J.P. (2011). Antibacterial activity of methanolic and acetone extract of some medicinal plants used in India folklore. In International Journal of Phytomedicine, vol. 3, p. 261-269

Phillipson, A.H. (1970). Physiology of digestion and metabolism in the ruminants.Oriel Press, Newcastle Upon Tyne, England. (C. F. Marei (2007)). Reyes Sa'nchez, N.; B. Eva Spo“ rndly and IngerLedin (2006).Effect of feeding different levels of foliage of Moringaoleifera to Creole dairy cows on intake, digestibility, milk production and composition. Livestock Science 101:24-31.

Platel K, Rao A, Saraswathi G, Srinivasan K,(2002). Digestive stimulant action of three Indian spice mixes in experimental rats, Die Nahrung, 46 (6), 2002, 394-398.

Pluske JR, (2013). Feed- and feed additives-related aspects of gut health and development in weanling pigs, Journal of Animal Science and Biotechnology, 4, 2013, 1.

Ray-Yu Yang1*, Lien-Chung Chang2, Jenn-Chung Hsu3, Brian B. C. Weng4, Manuel C. alada5, M. L. Chadha6 and Virginie Levasseur7, (2006). Nutritional and Functional Properties of moringa Leaves From Germplasm, to Plant, to Food, to Health.Moringa and other highly nutritious plant resources: Strategies, standards and markets for a better impact on nutrition in Africa. Accra, Ghana, November 16-18, 2006

Reyes Sanchez N, Sporndly E, Ledin I (2006). Effects of feeding different levels of foliage from MoringaOleifera to creole dairy cows on intake, digestibility, milk production and composition.Livest. Sci. 101(1-3): 24-31.

Rock MJ, Kincaid RL, Carstens GE (2001). Effects of prenatal source and level of dietary selenium on passive immunity and therumen metabolism of newborn lambs. Small Ruminant Res., 40: 129-138.

Sanchez-Machado DI, Nunez-Gastelum JA, Reyes-Moreno C, Ramirez-Wong B, Lopenz-Cervantes J (2009). Nutritional Quality of edible Parts of Moringaoleifera. Food Anal Method DOI 10.1007/s1261 009-9106-Z.

Sarwatt SV, Milang'ha MS, Lekule FP, Madalla N (2004). Moringaoleifera and cottonseed cake as supplements for smallholder dairy cows fed Napier grass. Lives Res Rural Dev., vol. 16.

SAS (2003). Statistical Analysis System Institute Inc. Users Guide, Version 9, USA.

Sultana N., Alimon, A, Hoque, K. S., Sazili, A. Q., Yaakub, H., Hossin, J and Baba, M. (2015). The feeding value of Moringa (Moringa Oleifera) foliage as replacement of concentrate diet in Bengal goats. Advances in Animal and Veterinary Science. Vol. 3 Issue 3 P. 164.

Soetan, K.O. and Ooyewole, O.E. (2009). The need for adequate processing to reduce the anti-nutritional factors in animal feeds: A review. In African Journal of Food Science, vol. 3, no. 9, p. 223-232. 
Sofidiya, M.O, - Odukoya, O.A, - Familoni, O.B. and Inya-agha, S.I. (2006). Free-radical scavenging activity of some Nigerian medicinal plant extracts. In Pakistan Journal of Biological Science, vol. 9, p. $1438-1441$.

Tsedeke K,. (2007). Production and marketing of sheep and goats in Alaba, Southern Nations ationalities and Peoples Region SNNPR, Msc thesis, Hawassa University, Hawassa, Ethiopia, 2007.

Van Soest PJ, Robertson JB, Lewis BA (1991). Methods for dietary fibre, neutral detergent fibre, and nonstarch carbohydrates in relation to animal nutrition. J. Dairy Sci., 74: 3583-3597.

Van Soest, P. J. (1994). The Nutritional Ecology of the Ruminant, 2nd edition.Cornell University Press. Ithaca, NY., $476 \mathrm{p}$.

Warner, A.C.I. (1964). Production of volatile fatty acids in the rumen, methods of measurements.Nutr.Abst.and Rev., 34:339.

Worku A., (2016): Moringa oleiferas a Potential Feed for Livestock and Aquaculture Industry.Arba Minch University, College of Agricultural Sciences, Department of Animal and Range science. Po.box-21. email:alexovichsh@yahoo.com.

Yang, R.Y., Tsou, S. C. S., Lee, T. C., Chang, L. C., Kuo, G., and Lai, P. Y.( 2006). Moringa, a novel plant rich in antioxidants, bioavailable iron, and nutrients.pp224-239. In: C. T. Ho (ed) Challenges in Chemistry and Biology of Herbs. Moringa and other highly nutritious plant resources: Strategies, standards and markets for a better impact on nutrition in Africa. Accra, Ghana, November 16-18, 2006. American Chemical Society, Washington, D.C.

\section{تأثير إضافة اوراق المورنجا على وظائف الكرش، الهضم و الثوارد الحرة والاداعالانتاجى للحملان النامية}

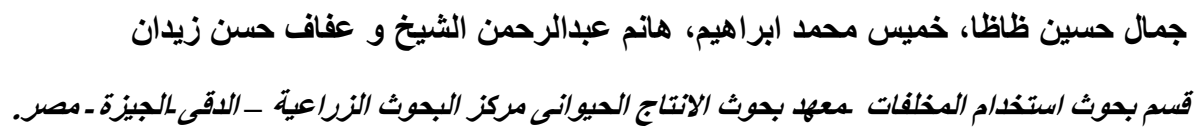

يهدف هذا البحث الى در اسة اثر المو اد المضادة للاكسدة فى اور اق المورنجا كاضافة علفية وتاثر ها على الماكول من المركبات الغذائية،

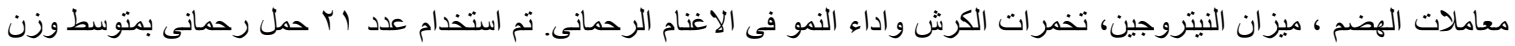

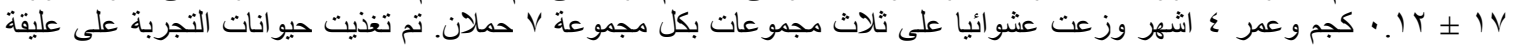

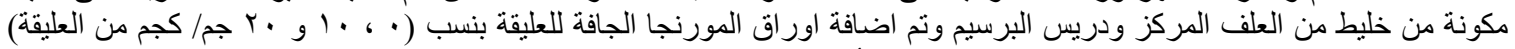

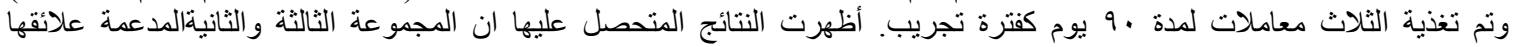

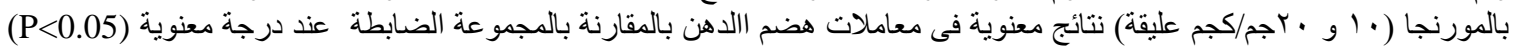

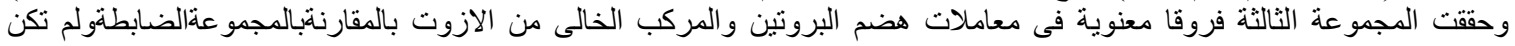

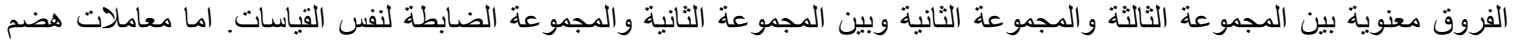

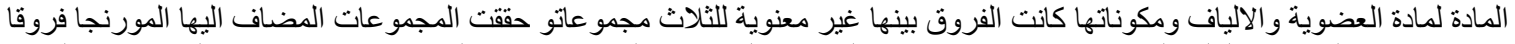

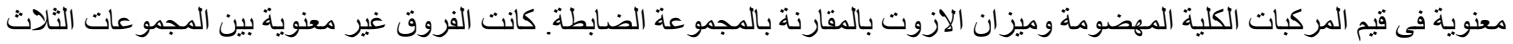

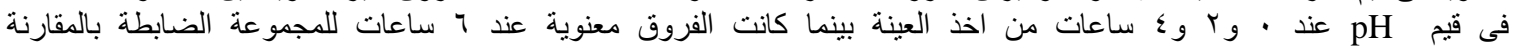

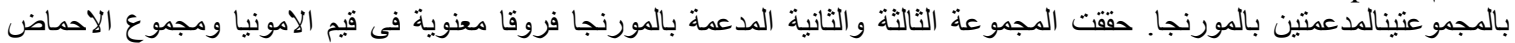

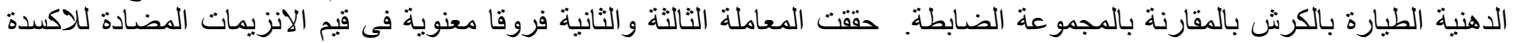

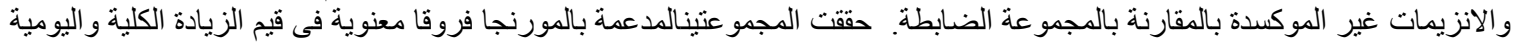

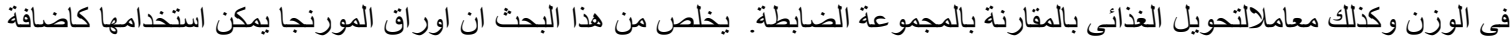

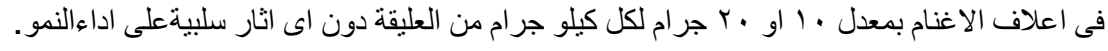


Table (1): Nutrient contents of Moringa leaves

\begin{tabular}{lc}
\hline \multicolumn{1}{c}{ Item } & $\%$ \\
\hline Nutrients analyzed of Moringa leaves $(\% \mathrm{DW})$ & \\
$\mathrm{DM}$ & 23.10 \\
$\mathrm{OM}$ & 91.79 \\
$\mathrm{CP}$ & 24.44 \\
$\mathrm{CF}$ & 3.43 \\
$\mathrm{EE}$ & 2.51 \\
$\mathrm{NFE}$ & 61.41 \\
Ash & 8.21 \\
\hline Non-enzymatic antioxidants in Moringaoleifera leaves & \\
Ascorbic acid $(\mathrm{mg} / \mathrm{g})$ & 5.82 \\
Tocopherol $(\mu \mathrm{g} / \mathrm{g})$ & 5.91 \\
Zinc $(\mathrm{Zn})(\mathrm{mg} / \mathrm{Kg})$ & 1.82 \\
Selenium $(\mathrm{Se})(\mathrm{mg} / \mathrm{Kg})$ & 0.11 \\
\hline
\end{tabular}

Table (2): Chemical composition of feed ingredients and the formulated rations \% (on DM basis)

\begin{tabular}{cccc}
\hline Item & Clover hay & Concentrate feed mixture & Control ration \\
\hline OM & 89.41 & 88.06 & 88.46 \\
CP & 12.33 & 14.96 & 14.18 \\
CF & 26.29 & 12.11 & 16.37 \\
EE & 1.91 & 5.38 & 4.34 \\
NFE & 48.88 & 55.61 & 53.57 \\
Ash & 10.59 & 11.94 & 11.54 \\
NDF & 51.96 & 36.27 & 40.98 \\
ADF & 35.33 & 22.1 & 26.09 \\
\hline
\end{tabular}


Table (3): Digestibility, nutritive values and nitrogen balance ofexperimental rations.

\begin{tabular}{lcccc}
\hline Item & \multicolumn{3}{c}{ Experimental rations } & \\
\cline { 2 - 4 } & $\mathrm{R}_{1}$ & $\mathrm{R}_{2}$ & $\mathrm{R} 3$ \\
\hline Intake & & & & \\
DM intake(g/day) & 1068.57 & 1079.76 & 1103.52 & \\
Digestibility coefficients \% & & & & 1.02 \\
OM & 70.39 & 71.62 & 73.12 & 0.54 \\
CP & $70.8^{3 \mathrm{~b}}$ & $72.65^{\mathrm{ab}}$ & $73.82^{\mathrm{a}}$ & 0.71 \\
CF & 50.65 & 51.46 & 53.16 & 0.31 \\
EE & $80.89^{\mathrm{b}}$ & $82.84^{\mathrm{a}}$ & $83.08^{\mathrm{a}}$ & 0.32 \\
NFE & $75.74^{\mathrm{b}}$ & $76.61^{\mathrm{ab}}$ & $77.15^{\mathrm{a}}$ & 0.03 \\
NDF & 65.76 & 66.16 & 66.49 & \\
ADF & 58.75 & 59.18 & 59.86 & 0.65 \\
Nutritive value \% & & & 0.41 \\
TDN & $66.66^{\mathrm{b}}$ & $67.85^{\mathrm{ab}}$ & $69.19^{\mathrm{a}}$ & \\
DCP & 10.04 & 10.30 & 10.47 & 0.33 \\
Nitrogen Utilization (g/day) & & & 0.54 \\
N I & 24.24 & 24.51 & 25.04 & 0.05 \\
N O & 22.53 & 22.59 & 22.98 & \\
N B & $1.71^{\mathrm{b}}$ & $1.92^{\mathrm{a}}$ & $2.06^{\mathrm{a}}$ & \\
\hline
\end{tabular}

$a, b$ and $c$ : Means in the same row with different superscripts are significantly different $(P<0.05)$.

Table (4): Rumen parameters of sheep fed the experimental rations.

\begin{tabular}{lcccc}
\hline & \multirow{3}{*}{ Item } & \multicolumn{2}{c}{ Experimental rations } & \multirow{2}{*}{$\mathrm{SE} \pm$} \\
\cline { 2 - 4 } $\mathrm{pH}$ & $\mathrm{R}_{1}$ & $\mathrm{R}_{2}$ & $\mathrm{R} 3$ & \\
Sampling time (hr): & & & & 0.12 \\
0 & 6.87 & 6.78 & 6.75 & 0.12 \\
2 & 6.25 & 6.21 & 6.17 & 0.05 \\
4 & 5.98 & 5.93 & 5.84 & 0.03 \\
6 & $6.57^{\mathrm{a}}$ & $6.41^{\mathrm{b}}$ & $6.36^{\mathrm{b}}$ & \\
$\mathrm{NH} 3-\mathrm{N}(\mathrm{mg} / 100 \mathrm{ml}$ & & & & 0.13 \\
Sampling time (hr): & & & & 0.08 \\
0 & $12.19^{\mathrm{b}}$ & $12.53^{\mathrm{b}}$ & $13.53^{\mathrm{a}}$ & 0.17 \\
2 & $14.56^{\mathrm{c}}$ & $16.80^{\mathrm{b}}$ & $18.54^{\mathrm{a}}$ & \\
4 & $18.51^{\mathrm{b}}$ & $18.97^{\mathrm{b}}$ & $21.32^{\mathrm{a}}$ & \\
6 & $15.17^{\mathrm{b}}$ & $15.51^{\mathrm{b}}$ & $16.76^{\mathrm{a}}$ & 0.22 \\
TVFA,s (meq/100 ml & & & & 0.12 \\
Sampling time (hr): & & & $8.03^{\mathrm{a}}$ & 0.13 \\
0 & $6.76^{\mathrm{b}}$ & $7.98^{\mathrm{a}}$ & $8.69^{\mathrm{a}}$ & \\
2 & $8.15^{\mathrm{b}}$ & $8.56^{\mathrm{ab}}$ & $11.51^{\mathrm{a}}$ & \\
4 & $10.38^{\mathrm{c}}$ & $10.87^{\mathrm{b}}$ & $8.56^{\mathrm{a}}$ & 0.06 \\
6 & $8.11^{\mathrm{c}}$ & $8.34^{\mathrm{b}}$ & \\
\hline a, b and c: Means in the same row with different superscripts are significantly different $(P<0.05)$. &
\end{tabular}


Zaza et al. 
Table (5): Effect of experimental rations on serum anti-oxidant status of tested lambs.

\begin{tabular}{|c|c|c|c|c|}
\hline \multirow{2}{*}{ Item } & \multicolumn{3}{|c|}{ Experimental rations } & \multirow{2}{*}{ \pm SE } \\
\hline & $\mathrm{R}_{1}$ & $\mathrm{R}_{2}$ & $\mathrm{R}_{3}$ & \\
\hline \multicolumn{5}{|l|}{ Enzymatic Antioxidants } \\
\hline Glutathione peroxidase $(\mathrm{U} / \mathrm{ml})$ & 23.64 & 24.17 & 23.97 & 0.24 \\
\hline Glutathione reductase $(\mathrm{U} / \mathrm{L})$ & $38.26^{\mathrm{b}}$ & $38.97^{\mathrm{a}}$ & $39.05^{\mathrm{a}}$ & 0.13 \\
\hline \multicolumn{5}{|l|}{ Non- enzymatic Antioxidants } \\
\hline Vitamin $\mathrm{C}, \mu \mathrm{mol} \mathrm{L}$ & $20.79^{\mathrm{c}}$ & $21.25^{\mathrm{b}}$ & $21.98^{\mathrm{a}}$ & 0.06 \\
\hline Vitamin $\mathrm{E}, \mu \mathrm{mol} \mathrm{L}$ & $3.85^{\mathrm{b}}$ & $4.06^{\mathrm{ab}}$ & $4.35^{\mathrm{a}}$ & 0.09 \\
\hline Zinc $(\mathrm{Zn}) \mu \mathrm{g} / \mathrm{dl}$ & $52.14^{\mathrm{c}}$ & $61.76^{\mathrm{b}}$ & $69.34^{\mathrm{a}}$ & 0.39 \\
\hline Selenium $(\mathrm{Se})(\mu \mathrm{g} / \mathrm{l})$ & $121.15^{\mathrm{c}}$ & $137.11^{\mathrm{b}}$ & $142.29^{\mathrm{a}}$ & 0.25 \\
\hline The overall total antioxidant capacity $(\mathrm{mmol} / \mathrm{L})$ & $0.84^{\mathrm{b}}$ & $0.98^{\mathrm{a}}$ & $1.05^{\mathrm{a}}$ & 0.03 \\
\hline
\end{tabular}

Table (6): Effect of experimental rations on growth performance of growing lambs.

\begin{tabular}{lcccc}
\hline \multirow{2}{*}{ Item } & \multicolumn{3}{c}{ Experimental rations } & \multirow{2}{*}{ \pm SE } \\
\cline { 2 - 4 } & $\mathrm{R} 1$ & $\mathrm{R}_{2}$ & $\mathrm{R}_{3}$ & \\
Body Change & & & & \\
Initial body weight (IBW), Kg & 17.12 & 16.86 & 17.38 & 0.38 \\
Final body weight (IBW), Kg & $25.86^{\mathrm{c}}$ & $26.68^{\mathrm{b}}$ & $27.91^{\mathrm{a}}$ & 0.27 \\
Weight gain, (Kg) & $8.74^{\mathrm{b}}$ & $9.82^{\mathrm{a}}$ & $10.53^{\mathrm{a}}$ & 0.27 \\
Daily weight gain, (g) & $97.16^{\mathrm{c}}$ & $109.09^{\mathrm{b}}$ & $117.05^{\mathrm{a}}$ & 1.14 \\
Feed Intake & & & & \\
Dry matter intake (DMI), (Kg) & 0.86 & 0.87 & 0.91 & 0.04 \\
TDN, (Kg) & 0.57 & 0.59 & 0.63 & 0.01 \\
CP, (g) & $86.38^{\mathrm{c}}$ & $89.63^{\mathrm{b}}$ & $95.26^{\mathrm{a}}$ & 0.34 \\
Feed conversion ratio (FCR) $(\mathrm{g} / \mathrm{g})$ & $8.85^{\mathrm{b}}$ & $7.98^{\mathrm{a}}$ & $7.77^{\mathrm{a}}$ & 0.18 \\
\hline
\end{tabular}

$a, b$ and $c$ : Means in the same row with different superscripts are significantly different $(P<0.05)$. 